\title{
Simultaneous Local Election in Indonesia: Is It Really More Effective and Efficient?
}

\author{
Rahmat Muhajir Nugroho, Anom Wahyu Asmorojati \\ Universitas Ahmad Dahlan, Indonesia. E-mail: rahmat.nugroho@law.uad.ac.id \\ Universitas Ahmad Dahlan, Indonesia. E-mail: anom.asmorojati@law.uad.ac.id
}

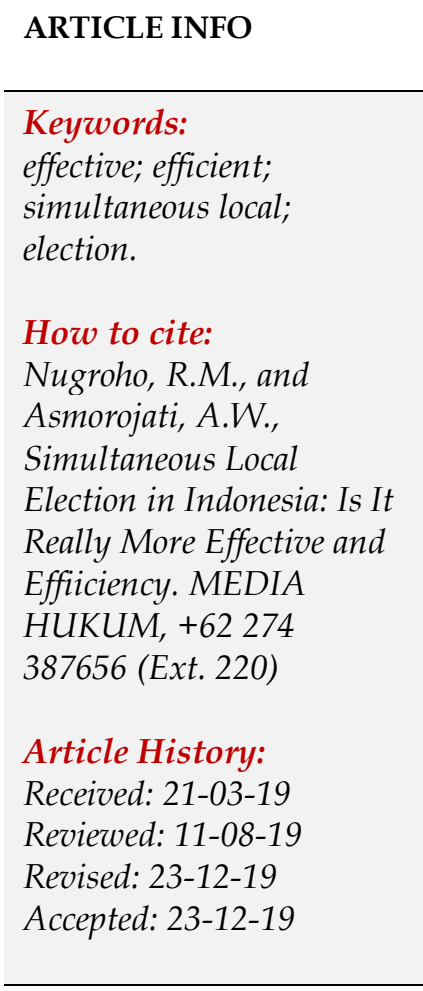

\begin{abstract}
Election system that is not carried out simultaneously, among others, has led to high political costs of local election. One of the objectives of the simultaneous local election design is the budget efficiency of the election implementation. This study aims to evaluate whether the simultaneous local election implementation may create a more effective and efficient local elections in the Special Region of Yogyakarta and South Kalimantan. This research was conducted using a normative juridical approach by analysing the applicable legal regulations, particularly Law Number 8 of 2015. In addition, an empirical juridical approach was used to see the implications of the establishment of Law Number 8 of 2015 on the Local Election. The results of study showed that the simultaneous local elections held in the Special Region of Yogyakarta and South Kalimantan were more effective and efficient in terms of controlling and solving problems, budgeting and time used for the implementation of the local election.
\end{abstract}

DOI: $10.18196 / j m h .20190135$

Copyright (C) $x x x x$ MEDIA HUKUM. All rights reserved.

\section{Introduction}

The simultaneous regional head election is regulated in Article 3 paragraph (1) of Law No. 8 of 2015 which states that "Elections are held once every 5 (five) years simultaneously in all regions of the Republic of Indonesia". The implementation of simultaneous local elections was divided into three batches. The first batch was carried out in December 2015, the second was in February 2017, and the third was in June 2018. After completed, the simultaneous national election will be implemented in $2027 .{ }^{1}$

\footnotetext{
${ }^{1}$ Risfil, A. (2015). http:// www.teropongsenayan.com/8889-kpu-resmi-umumkan-pilkadaserentak-2015, Accessed on Saturday, 25 April 2015 at 15:38.
} 
One of the objectives of the simultaneous local election design is the budget efficiency of the elections. Based on the data collected by the government, the percentage of the cost of conducting a local election in a province and regency/city ranges from $0.5 \%$ to $5 \%$ of the total amount of the regional budget. These costs include funding to the General Election Committee (KPU), Election Supervisory Agency (Bawaslu), Indonesian National Military (TNI)/National Police (Polri) as well as the needs of internal local governments, such as mobilizing security assistance and monitoring the budget of the political nation united agency/Office. ${ }^{2}$

Election system that is not carried out simultaneously, among others, has led to inflate political costs. The Indonesian Forum for Budget Transparency (FITRA), for example, noted that the cost of district or city local elections reached IDR 25 billion, while the provincial election costs IDR 100 billion. According to FITRA, in general, the election costs incurred by the government reached around IDR 17 trillion. ${ }^{3}$

The amount of money used in the elections has caused a number of negative impacts. Local elections do not create good governance. Instead, it tends to produce bad governance and/or divided governance. The indications are, among others, seen from the many regional leaders who broke the law. During 2005-2013, 25 regional leaders were imprisoned. 4

One of the underlying assumptions to save the local election budget is by conducting simultaneous election of the governors within one district/city. However, the efficiency cannot be achieved if the elections are not implemented at the same time, as what happened in the current transition period (2015-2019).

Meanwhile, simultaneous local election may cause ineffectiveness in terms of administrative duties of the government, such as cuttings or the extension of the term of office (for temporary officers), to suffice the implementation, which is divided into three batches.

In addition, the absence of separation between the regional head and deputy regional head in the procedure for election according to Law No. 8 of 2015, brings back the disharmony between the regional head and his deputy. Based on data from Ministry of Home Affair, since 2010 until now, there are only 50 Regional Heads and Deputy Regional Heads $(+7 \%)$ who paired up for the second time. The rivalry between the regional head and the deputy regional head became more crystallized when each of them became a regional head candidate in the elections. ${ }^{5}$

To ensure that the direct regional elections follow democratic principles, their implementation must be carried out with a system based on the free and fair principle through a good and integrative system. The ways include providing material and formal legal frameworks that is binding and becomes a guideline for the organizers, contestants (candidate pairs), and voters in fulfilling their respective roles and functions. Another way is by conducting all activities or stages that are directly related

\footnotetext{
2 Djohan, D. (2014). "Pilkada di Era Otonomi Daerah: Sebuah Tinjauan Kritis atas Agenda Demokrasi Indonesia", Proceeding Konferensi Hukum Tata Negara dan Anugerah Muhammad Yamin, Sawahlunto, 29 May-1 June 2014, p. 72.

3 Zuhro, S. (2014). "Urgensi Pilkada Serentak", Proceeding Konferensi Hukum Tata Negara dan Anugerah Muhammad Yamin, Sawahlunto, 29 May-1 June 2014, p. 75.

${ }^{4}$ Ibid.

5 DJohan, D. Loc.cit.
} 
to the implementation of regional head elections based on statutory provisions, as well as integrating the law enforcement (electoral law enforcement) of the regional head election rules in accordance with the stages at each level, both concerning administrative, criminal, ethical issues, and also disputes over results. ${ }^{6}$

The regulations of regional elections in Indonesia have never moved to a decentralized pattern. Any change ran slowly and obstructed. It can be traced from the Dutch East Indies to this post-reform era. In the various laws and regulations in the period after the proclamation to the beginning of the New Order, the regional heads were selected in two ways: appointed by a top-level official or proposed by the DPRD to be elected by the President or the Minister of Interior Home Affairs to become the regional head.

The Law No. 18 of 1965 represents the authoritative characters regarding the local election. The regional head is selected by the state official, thereby preventing the people from participating in the process.

Regulations regarding the election of regional heads have changed with the enactment of Law No. 5 of 1974 concerning the Principles of Regional Governments. According to the law, the election is carried out by the Regional Legislative Council (DPRD). However, the central government have more significant portion in carrying out the implementation, such as selecting the regional head, both for governor election and regent or mayor election. In other words, the law confirms the fulfillment of the central government's interests. Since the candidates have been prepared by the central, the DPRD merely serves as the "committee" of the regional head elections. ${ }^{7}$

As it is believed that there is a raison d'etre and urgency why the elections must be directly elected by the people, not through the DPRD. This is due to the local election through DPRD suffering from a number of weaknesses, namely: (1) the election of regional heads through DPRD tends to be more oligarchic and elitist, where only the elite leaders of the party and DPRD members are entitled to determine someone is elected as regional head; (2) the elected regional head is not necessarily in accordance with the aspirations and desires of the wider community or the people as the owner of the highest sovereignty; (3) the election of regional heads through the DPRD causes the elected regional heads to be very dependent on the DPRD so that it is less aspirational to regional aspirations and interests .8

Meanwhile, the direct election chosen by the people provides several advantages. First, to break the oligarchy and the elitist role of DPRD in determining regional heads. Second, elected regional heads have a direct mandate from the people and have strong legitimacy. Third, strengthen the accountability and responsibility of elected regional heads to the people. Fourth, direct elections will increase participation. ${ }^{9}$

Similarly, the simultaneous regional head election model set out in Law No. 8 of 2015 does not accommodate the elections at the local level, in the sense that the regional head elections are synchronized with the election of DPRD members. According to

\footnotetext{
6 Nasrullah \& Lailam, T. (2017) “Dinamika dan Problematika Politik Hukum Lembaga Penyelesai Sengketa Hasil Pemilihan Kepala Daerah di Indonesia", Jurnal Media Hukum, 24(1): 7.

7 Sulardi \& Sulistyaningsih, T. (2017) “Konstruksi Regulasi Sistem Pemilihan Kepala DaerahMenuju Sistem Pemilihan Kepala Daerah Yang Demokratis", Jurnal Media Hukum, 24(1): 4-5.

8 Romli, L. (2018) “Pilkada Langsung, Calon Tunggal, dan Masa Depan Demokrasi Lokal”, Jurnal Penelitian Politik, 15(2): 9.

${ }_{9}$ Ibid.
} 
Ramlan Surbakti, to ensure the effectiveness of regional government, synergic cooperation between the regional head and the DPRD is necessary. That is to say, the regional head election must also be concurrent with the election of the DPRD members. ${ }^{10}$

Based on the above background, this study is questioning the implications of the simultaneous local election implementation for the effectiveness and efficiency of the election based on Law No. 8 of 2015 concerning the Election of Governors, Regents, and Mayors.

The purpose of this study is to describe the implications of the simultaneous local elections on the effectiveness and efficiency of the elections held in the Special Region of Yogyakarta and South Kalimantan.

\section{Method}

In accordance with the specifications, this research belongs to descriptive analytic type. It seeks to present the data as completely as possible. The data used is primary and secondary data. The data were organized and classified to systemize and integrate the facts about the state of the object under the study. The secondary data consist of primary, secondary, and tertiary legal materials. The description of facts is intended to be analyzed and tested based on theoretical assumptions or propositions with the possibility of affirming, refining, and finding a new theory. ${ }^{11}$

Based on the nature of the research, this research was conducted using a normative juridical approach, which is an approach that conceptualizes the law as norms, rules, principles, or dogmas through organizing and classifying data systematically by analyzing the applicable legal regulations, particularly Law Number 8 of 2015. Furthermore, an empirical juridical approach is used to see the implications of the issuance of Law No. 8 of 2015 for the effectiveness and efficiency of the elections in Yogyakarta and South Kalimantan. ${ }^{12}$

To produce a complete description of the object under study, the normative juridical approach is carried out through historical studies ${ }^{13}$ and comparative studies. Historical studies are aimed to find the legal materials about the history of the local elections in Indonesia. Meanwhile, a comparative study was conducted to compare the implementation of local elections before and after the enactment of Law Number 8 of 2015 , in order to find the ideal design for the simultaneous election. The data were collected through literature study and field study. The document study was on the content analysis of the legal materials found in the library ${ }^{14}$. These legal materials are varied. First is the primary legal materials in the form of laws and regulations relating to the object of the research. These materials consist of the 1945 Constitution as well as the laws and regulations concerning the Regional Government and the election of regional heads. Second is the secondary legal material in the form of article explanation

\footnotetext{
10 Surbakti, R. (2014). “Disain Pemilihan Umum Nasional Serentak: Concurrent Election dan Coattail Effect", Proceeding Konferensi Hukum Tata Negara dan Anugerah Muhammad Yamin, Sawahlunto, 29 Mei-1 Juni 2014, p. 24.

11 Soekanto, S. (1986) Pengantar Penelitian Hukum, UI Press Jakarta, Cetakan III, p. 9-10.

12 Soekanto, S. \& Mamudji, S. (2006). Penelitian Hukum Normatif, Jakarta: Rajawali Press, p. 14-15.

${ }^{13}$ Marzuki, P.M. (2006). Penelitian Hukum, Jakarta: Kencana Prenada Media Group, hlm. 126

14 Ibid., p. 2.
} 
of a statutory regulation, books, research results, papers, scientific, and journals. The third is tertiary legal materials in the form of statements or opinions from legal experts, encyclopedias, and legal dictionaries relevant to the object under study.

The library research is carried out in several places. Among others are the libraries in various universities, regional libraries, and study centers. Materials from the Internet are also included. In addition, field research was taken to support and complete the data that were not found in the mentioned study. The researcher interviewed the resources, such as the legal experts as well as the bureaucracy and KPU commissioners in the Special Region of Yogyakarta and South Kalimantan. After all the data were complete, they were matched with the problem of the study. The data were organized, classified, systemized, and then presented in descriptive juridical form. Then, qualitative juridical form was taken to reflect and abstract the data in general description and explanation based on theoretical propositions. The criteria should be prescriptive to create an effective and efficient simultaneous regional election design in the administration of the local government. ${ }^{15}$

\section{Results and Discussion}

Before the regulations on simultaneous local elections were established, the elections were simultaneously held by the Election Commission of each region, which may vary from one area to another. It can be conducted simultaneously due to the end of terms of office, which are almost the same.

\subsection{Effectiveness and Efficiency of the Regional Head Elections in South Kalimantan and Yogyakarta}

Effectiveness according to Othenk (2008) is the use of certain amounts of resources, facilities and infrastructure that are consciously determined in advance to produce a number of goods for the services that they carry out. Effectiveness shows success in terms of whether or not the target has been set. If the results of the activities are getting closer to the target, then the higher the effectiveness. Furthermore, Othenk (2008) emphasized that effectiveness is the utilization of certain amounts of resources, facilities and infrastructure that are consciously determined in advance to produce a number of jobs on time. It can be concluded that effectiveness is related to the implementation of all the main tasks, achievement of objectives, timeliness, and active participation of members as well as the relationship between objectives and stated results, and shows the degree of conformity between stated objectives and the results achieved.16

Efficiency is the ratio between output and input. Efficient measures can be developed by linking actual costs to predetermined standard costs (Halim, 2001). Whereas Deddi \& Ayuningtyas (2010) suggested that efficiency is the relationship between goods and services produced in an activity or activity with the resources used. An organization, activity or program can be said to be efficient if it is able to produce certain outputs

\footnotetext{
15 Soekanto, S. Pengantar Penelitian...Op.Cit., hlm. 13.

16 Sarjiyanto. (2018). "Efektivitas dan Akuntabilitas Penyelenggaran Anggaran Pilkada Serentak di Indonesia". Jurnal Ekonomi Pembangunan, 10(1):51-52.
} 
with the lowest possible input, or with certain inputs capable of producing maximum output (spending well). ${ }^{17}$

According to Samahuddin, Chairperson of the Provincial Election Committee of South Kalimantan Province, simultaneous local election is, indeed, more efficient and effective, compared to the other type. However, it has some weaknesses related to the regulatory issues (KPU regulations). The Committee should prepare the regulations far much in advance associated with the technical issues in the field, such as collecting the voters' data. Another drawback is related to budgeting, in that it should be independent. 18

Budget efficiency can occur because of the share between the regional budget of the province and that of the regency/city. Nevertheless, the share serves only as ad hoc benefits. The budget for the elections in South Kalimantan was IDR 110 billion, while the expense was around IDR 90 billion. The 2015 budgeting was lower than the previous election in 2010.19

Likewise, according to Hamdan Kurniawan, Chairperson of the Election Committee of the Special Region of Yogyakarta, the simultaneous local elections are more effective and efficient. The effectiveness can be seen in the regulations (rules) which are made to be uniform, such as the regulations and the technical SOPs, making the procedures understandable for all organizers of the elections. The uniformity prevents any region to improvise the regulations, regardless in the small scale. A Case in point, the problem encountered by the Committee in Sleman (2015) can be solved by the circular letter made by the central. In other words, the case was not resolved based on the locality, and therefore the policies are not heterogeneous in nature. ${ }^{20}$

The Sleman Regional Election case referred to was about the candidacy of a member of PDIP, namely Mrs. Muslimatun. The party had another candidate and did not confirm her. At the same time, she was proposed by another party but she had to resign from the regional legislative council. It could not be resolved since PDIP had not accomplished the Interim Replacement. To this, the KPU issued a circular letter, affirming by the terms, "as long as the person concerned is earnest about the resignation process." The keyword "earnest" is the base to resolve the problem. The KPU considered that the political right of an individual should not be hampered by other institution. The circular letter helped Mrs. Muslimatun to take the candidacy. In this case, the KPU saw the substance, instead of the procedures. ${ }^{21}$

In terms of budget efficiency, Yogyakarta succeeded in saving the budget, similar to those in South Kalimantan even if there was no simultaneous election in the Special Region for the province and the regency/city.22 The budget was distributed to each regency/city for the election in those levels. The chairperson of the General Election Committee of Yogyakarta stated that the simultaneous election is efficient, in that sense the budget for the polling station committee (KPPS) can be saved. It can be taken from

\footnotetext{
17 Ibid.

18 Wawancara langsung dengan Ketua KPU Kalsel pada tanggal 21 Agustus 2017 di Banjarmasin.

19 Ibid.

20 Wawancara langsung dengan Ketua Komisi Pemilihan Umum Daerah Istimewa Yogyakarta pada tanggal 21 Agustus 2017 di Yogyakarta

${ }^{21}$ Ibid.

22 Ibid.
} 
only one source, either from the province or from the regency/city. In the case of Yogyakarta, both types of elections produce similar efficiency..$^{23}$

Besides the budget, there is also efficiency in time. Simultaneous election is easier to manage. All levels share the responsibilities, ensuring the success of the election at the regency level. If the elections are held at different time, they may take a lot of time and energy. The simultaneous election allows the KPU to distribute any information at one time. ${ }^{24}$

3.2. Implications of Simultaneous Regional Head Election for the Effectiveness and Efficiency of Organizing Regional Head Elections Based on Law Number 8 of 2015.

An analysis on how the implications of the Direct Local Election on the responsibility of the Regional Head in the preparation of the Regional Development Program is important. What is the matter with the direct local elections, the direct election of regional heads is far better than being elected by the DPRD. With direct elections, in this case direct democracy can be carried out better, so that the meaning of sovereignty in the hands of the people is truly evident. Second, the Regional Head has broad support from the people so that he has strong legitimacy. Logically the regional government is strong and not easily shaken by the DPRD. Third, the people's voice becomes very valuable. This means that the interests of the people may get greater attention by anyone who wishes to run for Regional Head. Fourth, the game of money politics is reduced is simply it is not possible to bribe more than half the number of voters to win the Regional Head election. ${ }^{25}$

The direct election of regional heads (pilkada) is one of the significant political breakthroughs in realizing democratization at the local level. Not a few democratic theorists who say that basically all politics is local. That is, democracy at the national level will grow and develop well if supported by the solid values of local democracy. Local elections are part of the process of strengthening and deepening democracy as well as efforts to realize effective governance. ${ }^{26}$

One of the implications of simultaneous local election is the cut of the terms of office of the Governor/Regent/Mayor who joins the candidacy in the election. It is in accordance with the Law Number 8 of 2015 and Law Number 10 of 2016. To fill in the vacancy, there will be a Task Executor (PLT). The question is whether the government will operate effectively and efficiently with this Executor.

According to Said Abdullah, the Regional Secretary of Banjarbaru City South Kalimantan, the term of office for all regional heads is five years. During the simultaneous election, the term is cut and they will be replaced by a task executor (PLT). In this case, a task executor cannot take any strategic policy. Instead, he takes

\footnotetext{
23 Ibid.

24 Ibid.

${ }^{25}$ Hakim, L. (2010) “Implikasi Pilkada Langsung terhadap Pertanggungjawaban Kepala Daerah dalam Penyusunan Program Pembangunan Daerah", Jurnal Konstitusi, III(1):5

${ }^{26}$ Solihah, R "Politik Transaksional dalam Pilkada Serentak dan Implikasinya Bagi Pemerintahan Daerah di Indonesia", The Politics, 2(1): 2.
} 
administrative task only. The task executor will not obstruct the effectiveness and goals of the regional long-term or short-term plans, because he works administratively. ${ }^{27}$

The Chairperson of the Election Committee of the Sleman Regency stated that the effectiveness of the simultaneous election is still debatable, since it is for the interest of the election, instead of the government. The government effectiveness can only be measured by the related local government, while it simultaneously succeeded because the task executors were appointed at the same time. Besides, the central government supervises the local government, for example by assigning task executor to replace the previous officers who run for candidacy. ${ }^{28}$

According to Masrur Auf Ja'far, a member of the DPRD of South Kalimantan Province, no serious problem was found in terms of the government administration. The potential problem may appear incidentally. Masrur Auf further said that the terms of office should be reviewed. If a regional head runs for a candidacy for the upcoming election, the term will likely end in less than two years. Meanwhile, he needs to gain the votes. He suggested extending the term up to six or seven years. ${ }^{29}$

In line with Auf's statement, Hamdan claimed that the elected regional head in the initial period of 1 or 2 years would not be able to do much. He needs consolidation to plan the strategies to actualize the programs he proposes during the campaign.

Thus, the simultaneous local election that has been carried out in several regions in Indonesia has positive implications for the effectiveness and efficiency of governance. Positively, the interim government held by the task executor can carry out the duties and functions of the government regularly. In addition, with simultaneous local elections, the central government can monitor the task executors more easily in carrying out its duties. ${ }^{30}$ However, they cannot take strategic policies in the government. They are not authorized to make new policies from the vision, mission, and work programs that have been set by the previous regional head. If the term of office of the task executors is too long, it may disrupt the development in the regions

\section{Conclusion}

Based on evaluation of implementation of local election in Yogyakarta and South Kalimantan, it indicates that the simultaneous local election has made a more effective and efficient local election. The effectiveness and efficiency of the implementation of local election can be seen from several aspects i.e. it is easier to control and solve any problems, more efficient of budget, shortening the time used for local election.

\section{Acknowledgments}

We would like to express our gratitude to the Ministry of Technology and Higher Education Research, Chairperson of the South Kalimantan Election Commission and

\footnotetext{
27 Wawancara langsung dengan Setda Banjarbaru, tanggal 22 Agustus 2017 di Banjarbaru, Kalimantan Selatan.

28 Wawancara langsung dengan Ketua KPU Kab. Sleman, tanggal 31 Agustus 2017 di Sleman.

29 Wawancara langsung dengan Anggota DPRD Provinsi Kalsel, tanggal 22 Agustus 2017 di Banjarmasin, Kalimantan Selatan.

30 Wawancara Langsung dengan Ketua KPU DIY Tanggal 30 Agustus 2017.
} 
Chairman of the Yogyakarta Special Election Commission, Ahmad Dahlan University, all research sources, proofreaders, and fellow students who helped carry out this writing.

\section{References}

Books:

Marzuki, P.M. (2006). Penelitian Hukum. Jakarta: Kencana Prenada Media Group.

Soekanto, S. (1986). Pengantar Penelitian Hukum. Jakarta: UI Press, Cetakan III.

Soekanto, S \& Mamudji, S. (2006). Penelitian Hukum Normatif. Jakarta: Rajawali Press.

\section{Journal Articles:}

Hakim, L. (2010). “Implikasi Pilkada Langsung Terhadap Pertanggungjawaban Kepala Daerah dalam Penyusunan Program Pembangunan Daerah", Jurnal Konstitusi, III(1):5

Nasrullah \& Lailam, T. (2017), "Dinamika dan Problematika Politik Hukum Lembaga Penyelesaian Sengketa Hasil Pemilihan Kepala Daerah di Indonesia", Media Hukum, 24(1): 7.

Romli, L (2018), “Pilkada Langsung, Calon Tunggal, dan Masa Depan Demokrasi Lokal", Jurnal Penelitian Politik, 15(2): 9

Sarjiyanto, (2018). "Efektivitas dan Akuntabilitas Penyelenggaran Anggaran Pilkada Serentak di Indonesia", Jurnal Ekonomi Pembangunan, 10(1):51-52

Solihah, R.(2016), "Politik Transaksional dalam Pilkada Serentak dan Implikasinya bagi Pemerintahan Daerah di Indonesia", The Politics, 2(1): 2

Sulardi \& Sulistyaningsih, T. (2017). “Konstruksi Regulasi Sistem Pemilihan Kepala Daerah menuju Sistem Pemilihan Kepala Daerah yang Demokratis", Media Hukum, 24(1): 4-5.

\section{Proceedings:}

Djohan, D. (2014). Pilkada di Era Otonomi Daerah: Sebuah Tinjauan Kritis atas Agenda Demokrasi Indonesia, Proceeding Konferensi Hukum Tata Negara dan Anugerah Muhammad Yamin, Sawahlunto, 29 Mei-1 Juni 2014.

Rohim, N. (2014). Gagasan Pemilukada Serentak dan Implikasinya Terhadap Pesta Demokrasi yang Efektif dan Efisien. Proceeding Konferensi Nasional Hukum Tata Negara dan Anugerah Muhammad Yamin, Sawahlunto, 29 Mei-1 Juni 2014.

Supriyanto, D. (2014). Bukan Pilkada Serentak. Tapi Pemilu Daerah, Proceeding Konferensi Nasional Hukum Tata Negara dan Anugerah Muhammad Yamin, Sawahlunto, 29 Mei-1 Juni 2014. 
Surbakti, R. (2014). Disain Pemilihan Umum Nasional Serentak: Concurrent Election dan Coattail Effect. Proceeding Konferensi Hukum Tata Negara dan Anugerah Muhammad Yamin, Sawahlunto, 29 Mei-1 Juni 2014.

Yusuf, S.E. (2009). Kedaulatan Rakyat dalam Perspektif Pancasila. Makalah disampaikan dalam "Kongres Pancasila" tanggal 30 Mei-1 Juni 2009 di Universitas Gadjah Mada Yogyakarta, yang diselenggarakan atas Kerjasama Mahkamah Konstitusi Republik Indonesia dengan Universitas Gadjah Mada.

Zuhro, S. ( 2014). “Urgensi Pilkada Serentak”. Proceeding Konferensi Hukum Tata Negara dan Anugerah Muhammad Yamin, Sawahlunto, 29 Mei-1 Juni 2014.

\section{Regulations:}

Undang-Undang Nomor 8 Tahun 2015 tentang Perubahan Atas Undang-Undang Nomor 1 Tahun 2015 tentang Penetapan Peraturan Pemerintah Pengganti Undang-Undang Nomor 1 Tahun 2014 tentang Pemilihan Gubernur, Bupati dan Walikota Menjadi Undang-Undang.

Undang-Undang Nomor 10 Tahun 2016 tentang Perubahan Kedua Atas UndangUndang Nomor 1 Tahun 2015 tentang Penetapan Peraturan Pemerintah Pengganti Undang-Undang Nomor 1 Tahun 2014 tentang Pemilihan Gubernur, Bupati dan Walikota Menjadi Undang-Undang.

Putusan Mahkamah Konstitusi Nomor 14/PUU-XI/2013.

\section{Internet:}

Risfil, A. (2015) http://www.teropongsenayan.com/8889-kpu-resmi-umumkan-pilkada-serentak-2015, Saturday, 25 April at 15:38. 